\title{
Розділ 3
}

\section{ІСТОРІЯ РОЗВИТКУ ПЕДАГОГІЧНОї ТЕОРІЇ ТА ОСВITHЬОÏ ПРАКТИКИ \\ CHAPTER 3}

\section{HISTORY OF DEVELOPMENT OF PEDAGOGICAL THEORY AND EDUCATIONAL PRACTICE}

\author{
УДК 37.014.3:005.591.452 \\ DOI: 10.31376/2410-0897-2019-2-40-165-172
}

\section{ВЗАЄМОВПЛИВИ НА МЕНЕДЖМЕНТ «ПЕДАГОГІКИ ПАРТНЕРСТВА» В УМОВАХ РЕАЛІЗАЦЇ̈ ЗАВДАНЬ НОВОЇ УКРАЇНСЬКОЇ ШКОЛИ}

\author{
Білянін Григорій Іванович \\ кандидат педагогічних наук, доцент, директор \\ Інститут післядипломної педагогічної освіти Чернівещької області \\ e-mail: biljanin@ukr.net \\ ORCID ID: 0000-0001-5864-8502
}

\author{
Поляк Олександра Василівна \\ кандидат наук з державного управління, доцент кафедри педагогіки, психології \\ та теорії управління освітою \\ Інститут післядипломної педагогічної освіти Чернівецької області \\ e-mail: olespoldep@ukr.net \\ ORCID ID: 0000-0002-2821-9122
}

\begin{abstract}
У науковій статті проаналізовано взаємовпливи сучасних типів середовища (сочіального, державного, громадського, інклюзивного, повночінного життевого та інших) як складових нового освітнього середовища та видів партнерства (соиіального, державного, громадського та іниих) в умовах реформування освіти, закладів освіти та органів місиевого самоврядування. Висвітлено потребу дієвості менеджменту «педагогіки партнерства» задля реалізації ключового завдання Нової української школи - формування випускника закладу освіти як особистості - патріота - інноватора.
\end{abstract}

Ключові слова: менеджмент, освітнє середовище, сочіальне партнерство, державно-громадське партнерство, Концепція Нової украӥнської школи Концепџія реформування органів місчевого самоврядування.

Постановка проблеми. Якість менеджменту в різних сферах суспільного життя в значній мірі залежить від середовища та системи відносин, які застосовуються. Сучасний менеджмент освіти в умовах НУШ будується на парадигмі зміни системи відносин, в основі чого - партнерство. Концепція Нової української школи проголошує, що одним 3 дев'яти ключових компонентів формули нової школи є: педагогіка, що грунтується на партнерстві між учнем, учителем і батьками [18]. Нова школа, значиться в документі, працюватиме на засадах «педагогіки партнерства», основними принципами якої $\epsilon$ : повага до особистості; доброзичливість і позитивне ставлення; довіра у відносинах; діалог - взаємодія взаємоповага; розподілене лідерство; принципи соціального партнерства (рівність сторін, добровільність прийняття зобов'язань, обов'язковість виконання домовленостей) [там само].

Такий підхід, як не дивно, дискутується сучасними педагогами - слухачами курсів підвищення кваліфікації інститутів післядипломної освіти, в тому числі Чернівецької області, які справедливо зауважують, що недостатньо удосконалювати якість відносин в системі освіти за допомогою принципів «педагогіки партнерства» у той час, коли в соціумі ці відносини залишаються розбалансованими і тому успіх партнерства в освіті постійно нівелюється. Цей чинник відмежованості та відірваності відносин в освіті та суспільстві був притаманний i 
попередньому періоду школи, які носили форму двопартнерства: вчитель-учень. I вони мають рацію, але якщо екстраполювати ці відносини в освіті на ситуацію до початку дії Концепції НУШ, де вони існували в більшій мірі у відокремленому освітньому середовищі. А 3 точки зору менеджменту - в найбільшій мірі у «внутрішньому середовищі» закладів освіти.

Окрім того, ще до моменту дії Концепції Нової української школи розпочалися досить складні процеси змін суспільних відносин на локальному рівні, які започатковано іншим урядовим документом - «Концепцією реформування місцевого самоврядування та територіальної організації влади в Україні», схвалену розпорядженням Кабінету Міністрів України» у 2014 році [17]. Адже однією зі складових мети реформування місцевого самоврядування визначено створення і підтримку «повноцінного життєвого середовища для громадян», a одним із важливих повноважень органів місцевого самоврядування $\epsilon$ забезпечення управління закладами середньої, дошкільної та позашкільної освіти [там само], які знаходяться на території ОМС.

Аналіз останніх досліджень і публікацій свідчить, що в Україні після затвердження Концепції НУШ започатковано розв'язання цієї проблеми, оскільки демонструється широкий спектр досліджень щодо розуміння «педагогіки партнерства». Так, на думку О. Вишневського, в основі «педагогіки партнерства» має бути спілкування, взаємодія та співпраця між учителем, учнем і батьками. Учні, батьки та вчителі, об'єднані спільними цілями та прагненнями, $є$ добровільними й зацікавленими спільниками, рівноправними учасниками освітнього процесу, відповідальними за результат. Учитель має бути другом, а родина - залучена до побудови освітньої траєкторії дитини. «Педагогіка партнерства» визначає істинно демократичний спосіб співпраці педагога і дитини, який не відкидає різниці в їхньому життєвому досвіді, знаннях, але передбачає безумовну рівність у праві на повагу, довіру, доброзичливе ставлення і взаємну вимогливість [1].

Хоча висловлена названим та іншими науковцями, в тому числі Т. Кравчинською [24] думка передувала прийняттю Концепції Нової української школи, але демонструє чітку модель трипартнерства: учитель-учень-батьки, яка і $є$ ключовою в Концепції НУШ. Цей підхід належить і В. Волковій, яка аналізує організацію навчально-виховного процесу на засадах педагогіки партнерства в умовах реалізації Концепції НУШ [22] та Л. Ніколенко, яка обгрунтовує педагогіку партнерства як умову реалізації завдань розвитку особистості дитини у контексті НУШ [25].

Формулювання мети статті. Таким чином, набуває нових відмінних характеристик середовище, в якому функціонує система освіти та змінюються рамкові умови відносин в освітній сфері та соціумі в цілому. Тому за мету визначено обгрунтування менеджменту «педагогіки партнерства» шляхом взаємодії та взаємопроникнення 3 наявними типами середовища та видами партнерств в умовах реформування системи освіти, закладів освіти, органів місцевого самоврядування задля реалізації ключового завдання Нової української школи - підготовки випускника школи як: особистості - патріота - інноватора.

Виклад основного матеріалу. Щодо характеристики середовищ, в яких функціонує система освіти, то автори цієї наукової праці попередньо вже зверталася до аналізу менеджменту освітнього середовища та його впливів на формування Нової української школи [3; 19]. В останній 3 названих зазначалося, що Концепція НУШ містить такі характеристики поняття «середовище», зокрема: багатокультурне середовище [18, с. 4], освітнє середовище $[18$, с. $7 ; 8 ; 23]$, сучасне освітнє середовище $[18$, с. 9], нове освітнє середовище $[18$, с. 15$]$, виховне середовище $[18$, с. 20], творче середовище $[18$, с. 28], сімейне середовище [18]. Інші джерела характеризують: соціальне середовище [3; 18], державногромадське середовище [20], а також наявність загальнозрозумілого віртуального середовища. Окрім того, пункт 1.13 Закону «Про освіту» застосовує та дає визначення: «інклюзивне освітнє середовище» - сукупність умов, способів і засобів їх реалізації для спільного навчання, виховання та розвитку здобувачів освіти з урахуванням їхніх потреб та можливостей [15].

Отже, до системи освіти мають відношення всі вище описані типи середовища, оскільки в цих середовищах функціонують заклади освіти, проживають споживачі освітніх 
послуг, відбувається освітній процес (пункт 1.16)[15] та здійснюється освітня діяльність (п. 1.17) [15].

Наступна складова аналізу менеджменту «педагогіки партнерства» обумовлюється впливами тих форм партнерств, які існують в різних типах середовища. Так, згідно Концепції НУШ, «педагогіка партнерства» будується за допомогою «соціального партнерства». Акцент на «соціальне партнерство» продиктовано не лише одним із семи згаданих вище принципів «педагогіки партнерства» у Концепції НУШ, але й функціонуванням системи освіти в соціальному середовищі, яке має наступну характеристику.

Отже, в Україні відносини як процес визначення та зближення позицій, досягнення спільних домовленостей та прийняття узгоджених рішень обумовлено в першу чергу Законом України «Про соціальний діалог» [16], стаття перша якого, між іншим, тлумачить «соціальний діалог» як процес визначення та зближення позицій, досягнення спільних домовленостей та прийняття узгоджених рішень сторонами соціального діалогу, які представляють інтереси працівників, роботодавців та органів виконавчої влади і органів місцевого самоврядування, 3 питань формування та реалізації державної соціальної та економічної політики, регулювання трудових, соціальних, економічних відносин, а також іншими законодавчими актами, наприклад [14]. Прийняттю законів України передували наукові дослідження, зокрема М. Бондаренко - про соціальний діалог [4], В. Варениця - про модель соціального діалогу в сучасній Україні [30], Г. Чанишева - про правовий характер соціального діалогу [13] тощо.

Але аналіз даного питання є важливим також з точки зору розуміння іншого підходу, яке науковець М. Головатий визначає як «соціалізація», що, на його думку, є «процесом становлення особистості, засвоєння індивідом цінностей, норм, установок, зразків поведінки, притаманних певному суспільству, соціальній групі, а також процес залучення індивіда до системи суспільних відносин, формування його соціального досвіду, становлення й розвиток як цілісної особистості» [2, с. 538]. Соціалізація передбачає взаємодію людини із соціальним оточенням, яке впливає на формування iї певних якостей та рис, на активне засвоєння й відтворення нею системних суспільних зв'язків.

Попри це, явища «соціалізації» та «соціальний діалог» не дають у повній мірі вважати «сочіальне партнерство» таким, що є обов'язково присутнім у мові та діях пересічних громадян держави. Тому актуальними є також ті наукової погляди, які збагачують розуміння щодо застосування даного принципу в реальному житті для розширення горизонтів діалогів, що важливо, в першу чергу, для молодого покоління. Тому Г. Савранська 3 цього приводу зауважує: відносини соціального партнерства можуть сприяти суспільній злагоді та спростити ціннісне включення України у світове співтовариство, що базується на правових i демократичних принципах свободи особи, толерантності та ліберальної економіки [11], А. Кудряченко [7] та А. Колот [5], досліджуючи європейський довід соціального партнерства, акцентують увагу на його важливості для молоді.

Заглиблення в процес соціального партнерства демонструють праці В. Новікова [9] та Р. Українець [27], які до елементів «соціального партнерства» відносять: постійний переговорний процес, постійно працюючі органи з урегулювання відносин; система контролю за виконанням домовленостей, робота експертів партнерських відносин, що аналізують стан та перспективи системи соціального партнерства; доведення ідей соціального партнерства до широких верств населення тощо. Ці форми, на думку Г. Трунової [12] та С. Попової [10], можливі в державному середовищі, адже суб'єктом «соціального партнерства» і є держава

Попри те, недостатньо вивченими залишаються не стільки проблеми формування та функціонування системи «соціального партнерства» в системі освіти, бо певні напрацювання вже є: М. Буковинська [21], С. Цюра [28] та інших, а фактично відсутність наукових поглядів щодо аналізу «соціального партнерства» як складової частини «педагогіки партнерства» в сучасних закладах освіти, на що і спрямований наш науковий аналіз.

Обгрунтоване вище дозволяе припустити, що саме розвиток «соціального партнерства» як частини «педагогіки партнерства» може сприяти становленню здобувачів освіти як особистостей, чим умовно дана відповідь на одне 3 поставлених завдань Новою українською 
школою.

Для узагальнення думки щодо впливу державно-громадського партнерство на формуваня патріота та інноватора, звернемося до сторінки 27 Концепції НУШ, на якій визначено: «буде створено нові можливості для розширення державно-громадського партнерства у сфері освіти через нові підходи для співфінансування й управління навчальними закладами» [18].

Для тлумачення змістовності даної тези Концепції НУШ звернемося до науковця В. Боделана, який зауважує: виокремлюють два види партнерства: «державно-громадське партнерство» та «громадсько-державне партнерство». У першому випадку зарубіжний досвід демонструє, що у світі таке партнерство розуміється як постійний діалог з громадськістю, залучення ii до прийняття державноуправлінських рішень. У другому випадку - це формування і розвиток підприємств, створених громадськими організаціями [20].

Він також вказує, що можна виділити декілька правових моделей «громадськодержавного партнерства» в зарубіжних державах: уряд-бізнес-фінансові партнери; уряд-бізнесінститути громадянського суспільства-наука; уряд-бізнес-громадськість; уряд-лідери суспільної думки-громадянське суспільство-місцева громада-фінансові інститути та інші. Що стосується практики запровадження «громадсько-державного партнерства», то треба відзначити відставання України від багатьох держав та відсутність ретельно опрацьованих правових основ такого виду взаємовідносин влади і суспільства [там само]. Щоправда, на нашу думку, такий підхід науковця потребує проведення інших наукових досліджень.

Сутністю «державно-громадянського партнерства», на думку В. Боделана, 3 врахуванням статей правових актів є активність і ініціатива суб'єктів державного управління, яка полягає у такому: створення належних умов для розвитку громадянського суспільства; запровадження громадського контролю за діяльністю влади, забезпечення незалежної діяльності інститутів громадянського суспільства, посилення їх впливу на прийняття суспільно важливих рішень, створення умов для забезпечення широкого представництва інтересів громадян в органах державної влади та органах місцевого самоврядування тощо [там само].

У контексті аналізованого звертаємо увагу на аналогічний підхід щодо видів управління. Так, С. Королюк досліджує «громадсько-державне управління» [6], а Г. Тодосова «державно-громадське управління» [26], що співзвучне 3 думкою В. Боделана про види партнерства. У зв'язку з обгрунтованим вище, можна допустити наступне: окреслені завдання НУШ щодо підготовки патріота можуть бути реалізовані в рамках та умовах функціонування державно-громадського партнерства, а інноватора - за допомогою громадсько-державного партнерства. Останнє - як формат інноваційності - простежується також у працях М. Яворського, який аналізує громадсько-державне партнерство при побудові інноваційних підходів на рівні регіонів [29], що можна екстраполювати на локальний рівень, де функціонують більшість закладів освіти.

Висновки. Висловлена думка щодо набуття нових відмінних характеристик середовища, в якому функціонує система освіти та зміни рамкових умов відносин в освітній сфері та соціумі сучасної України підтверджується отриманими нами науковими результатами наступного характеру. На основі аналізу тридцяти наукових праць українських вчених, власних попередніх публікацій, багаторічної практики освітньої діяльності нами доведено, що сучасне «нове освітнє середовище» в умовах Нової української школи функціонує паралельно у соціальному, державному, громадському, інклюзивному, віртуальному, внутрішньому середовищі закладу освіти, які є його складовими. Впродовж тривалого періоду в кожному 3 типів середовища сформувалися види відносин - соціальне партнерство, державно-громадське партнерство, громадсько-державне партнерство, що давало можливість еволюціонували від двопартнерства освітнього процесу - «учитель-учень» до трипартнерства освітнього процесу «учитель-учень-батьки» як пріоритету Концепції НУШ, в основі якої «педагогіка партнерства».

Баланс якості «педагогіки партнерства» залежить від системи менеджменту, якій належить застосовувати механізми та інструменти з врахуванням взаємовпливів та взаємодії 
типів середовища та видів партнерства.

Перспективи подальших розвідок у цьому напрямі стосуються розробки освітніх стратегій реалізації ключових завдань НУШ для випускника закладу освіти за напрямами:

- формування особистості - вплив пріоритетних типів середовища - форма партнерства для дієвого застосування,

- виховання патріота - вплив пріоритетних типів середовища - форма партнерства для дієвого застосування,

- навчання інноватора - вплив пріоритетних типів середовища - форма партнерства для дієвого застосування.

\section{Список використаної літератури}

1. Вишневський О. Теоретичні основи сучасної української педагогіки: посібник для студентів вищих навчальних закладів. Дрогобич: Коло, 2006. 326 с.

2. Менеджмент: Понятійно-термінол. слов. / за ред. Г. В. Щокіна, М. Ф. Головатого, О. В. Антонюка, В. П. Сладкевича. К.: МАУП, 2007. 744 с.

3. Поляк О. В. Менеджмент освітнього середовища та його впливи на формування нової української школи. Наукові підсумки 2018 року: зб. матеріалів доп. учасн. XXV Міжнар. Наук.-практ. інтернет-конф. Ч. 7. Педагогічні науки. Вінниця. 2018. С. 45-49. C. $173-174$.

4. Бондаренко М. Соціальний діалог: привід для розмов чи рішучих дій. Правовий тиждень. 2008. № 40.

5. Колот А. Соціальне партнерство на зламі двох тисячоліть: стан, виклики, тенденції розвитку (на прикладі країн Європейського Союзу). Соиіальна політика: проблеми, коментарі, відповіді. 2009. № 1. С. 26-28.

6. Королюк С. В. Особливості громадсько-державного управління в діяльності сучасної школи. Теорія та методика управління освітою. 2010. № 3. С. 1-13.

7. Кудряченко А. І. Соціальне партнерство: європейський досвід і Україна. Стратегічні пріоритети, 2008. № 3 (8). C. 132-141.

8. Макар Л. М. Сутність освітнього середовища в педагогічному процесі. Педагогіка формування творчої особистості у вищій і загальноосвітній школах. 2013. Вип. 30. С. 229-236.

9. Новіков В. Зарубіжний досвід соціального партнерства. Україна: аспекти праціi. 1998. № 1. С 38-41.

10. Попова С. В. Соціальне партнерство та аутсорсинг як напрями підвищення ефективності надання соціальних послуг в Україні Теорія та практика державного управління. 2014. Вип. 1. С. 156-162.

11. Савранська Г. М. Міжсекторне соціальне партнерство як основа соціальної безпеки держави. Науковоінформаційний вісник Академії національної безпеки. 2014. № 1. С. 93-105.

12. Трунова Г. А. Держава як суб'єкт соціального партнерства. Підприємниитво, господарство і право: Щомісячний науково-практичний господарсько-правовий журнал. 2007. № 1. С. $29-35$.

13. Чанишева Г. І. Соціальний діалог як інститут трудового права. Науковий вісник Міжнародного гуманітарного університету, 2015, № 18, том 2. С. 4-6.

14. Про колективні договори i угоди: Закон України від 01 лип. 1993 p. № 3356-XII. URL: http://zakon2.rada.gov.ua/laws/show/3356-12 (дата звернення: 17.03.2019).

15. Про освіту: Закон України від 19 січ. 2019 p. № 2657-VIII, 2661-VIII. URL: http://zakon.rada.gov.ua/laws/show/2145-19 (дата звернення: 25.02.2019).

16. Про соціальний діалог: Закон України від 23 груд. 2019 p. № 2862-VI. URL: https://zakon.rada.gov.ua/laws/show/2862-17 (дата звернення: 18.02.209).

17. Концепція реформування місцевого самоврядування та територіальної організації влади в Україні: Розпорядження Кабінету Міністрів України від 01 квіт. 2014 p. № 333-p. URL: https://zakon.rada.gov.ua/laws/show/333-2014 (дата звернення: 02.03.2019).

18. Концепція Нової Української Школи / M-во освіти i науки України. URL: https://www.kmu.gov.ua/.../ukrainska-shkola-compressed.pd (дата звернення: 01.03.2019).

19. Білянін Г. I. Сучасні інновації в системі освіти Чернівецької області. 2014. URL: irbisnbuv.gov.ua/.../cgiirbis_64.exe? (дата звернення: 27.02.2019).

20. Боделан В. Р. Правові основи громадсько-державного партнерства: зарубіжний і вітчизняний досвід. 2014. URL: official.chdu.edu.ua/article/viewFile/60352/56153 (дата звернення: 12.03.2019).

21. Буковинська М. П.Умови і принципи функціонування в освіті соціального партнерства. URL: http://www.rusnauka.com/15_APSN_2010/Economics/67941.doc.htm (дата звернення: 01.03.2019).

22. Волкова В. Організація навчально-виховного процесу на засадах педагогіки партнерства в умовах реалізації концепції Нової української школи. URL: https://naurok.com.ua/organizaciya-navchalno-vihovnogoprocesu-na-zasadah-pedagogiki-partnerstva-v-umovah-realizaci-koncepci-novo-ukra-nsko-shkoli-5829.html ） (дата звернення: 02.03.2019).

23. Сжова О. Є. Створення освітнього середовища спрямованого на формування ціннісного ставлення до здоров'я в учнів професійно-технічних навчальних закладів. 2011. URL: lib.iitta.gov.ua/.../Yezhova_Stvorenny_osvitnoho_seredovys (дата звернення: 08.03.2019).

24. Кравчинська Т. С. Педагогіка партнерства - основні ідеї, принципи та сутність. URL: 
lib.iitta.gov.ua/707221/1/Кравчинська_тези.pdf (дата звернення: 27.02.2019).

25. Ніколенко Л. Педагогіка партнерства як умова реалізації завдань розвитку особистості дитини у

контексті Нової української школи. 2018.

lib.iitta.gov.ua/.../Ніколенко_Методист_Ст.\%20Педаг.\%20партнерства\%20як\%20у. (дата звернення: 07.03.2019).

26. Тодосова Г. І. Шляхи розвитку державно-громадського управління освітою в Україні: європейський досвід та українська реальність. URL: http:/www.academy.gov.ua/ ej/ej11/txts/10thidur.pdf (дата звернення: 01.04.2019).

27. Українець Р. Узгоджувальні зустрічі - один з дієвих засобів переговорного процесу у прискоренні вирішення колективних трудових спорів (конфліктів). URL: http://www.nspp.gov.ua/index.php?option=com_conten (дата звернення: 09.03.2019).

28. Цюра С. Б. Нові моделі соціального партнерства школи і сім’ї: приватна загальноосвітня школа в Україні. 2012. URL: www.irbis-nbuv.gov.ua/cgi-bin/irbis_nbuv/cgiirbis_64.exe? (дата звернення: 16.03.2019).

29. Яворський М. Громадсько-державне партнерство при побудові регіональної інноваційної системи. URL: http://www.cstei.lviv.ua (дата звернення: 15.03.2019).

30. Варениця В. А. Становлення нової моделі соціального діалогу в сучасній Україні: соціологічний аналіз: автореф. дис. на здобуття наук. ступеня канд. соціолог. наук: 22.00.04. Харків, 2009. 22 с.

\title{
MUTUAL INFLUENCE ON THE MANAGEMENT OF «PARTNERSHIP PEDAGOGY» WHILE NEW UKRAINIAN SCHOOL TASKS REALIZATION
}

\author{
Bilianin Hryhorii \\ candidate of Pedagogical Sciences, Associate Professor, Director \\ Chernivtsi In-Service Teachers Training Institute
}

\section{Poliak Olexandra}

candidate of Science in Public Administration, associate professor of the chair of pedagogy, psychology and theoretical management in education

Chernivtsi In-Service Teachers Training Institute

Introduction. As the quality of management in all spheres of public life depends on the state of the environment and the system of relations, these components are crucial for educational management in order to realize the mission, goals and objectives of the New Ukrainian School. The problem is the mismatch between changing the quality of relations in the education system with the principles of "partnership pedagogy» when these relations remain unbalanced in the society, and therefore the success of partnership in education is constantly being leveled off.

Purpose. The aim is to determine the quality of the management of the "partnership pedagogy" through interaction and interpenetration with the existing types of environment and types of partnerships for the implementation of the key task of Nursing - preparing a graduate of the school as: personality - patriot - innovator in the conditions of the reform.

Methods. The authors of the paper use methods of scientific knowledge identification, analysis of legislation, comparative analysis - during the actualization of environmental notions: social, educational, inclusive, public, etc., and types of partnership: partnership pedagogy, social partnership, etc.

Results. It is proved that the balance of quality of "partnership pedagogy» depends on the management system, which should use mechanisms and tools, taking into account the interactions of different types of environment and different types of partnership.

Originality. The scientific novelty is to prove the key role of «social partnership» as part of the "partnership pedagogy», which takes place under the new conditions of mutual influence and interpenetration of environments, and hence an understanding of the new possibilities for becoming educators as personalities, patriots and innovators.

Conclusion. It is proved that the modern «new educational environment» in the conditions of the New Ukrainian School functions simultaneously in the social, state, social, inclusive, virtual, internal environment of the institution of education, which are its components. For a long period of time, in each of the types of environment, types of relations have been formed-social partnership, public-public partnership, public-state partnership, which allowed the opportunity to evolve from the 
two-party educational process - «teacher-student» to the tripartite educational process - «teacherstudent-parent» as a priority of the Concept of Nursery, which «pedagogy of partnership» is based on.

Key words. Management, educational environment, social partnership, state-public partnership, Concept of the New Ukrainian school, Concept of reformation of local self-government bodies.

\section{References}

1.Zakon Ukrainy «Pro kolektyvni dohovory i uhody» [The law of Ukraine «About collective agreements and agreements»]. (2015, January 01). Retrieved from http://zakon2.rada.gov.ua/laws/show/3356-12 [in Ukrainian].

2. Zakon Ukrainy «Pro osvitu» [The law of Ukraine «About education»]. (2019, January 19). Retrieved from http://zakon.rada.gov.ua/laws/show/2145-19 [in Ukrainian].

3. Zakon Ukrainy «Pro sotsialnyi dialoh» [The law of Ukraine «About social dialogue»]. (2010, December 23). Retrieved from https://zakon.rada.gov.ua/laws/show/2862-17 [in Ukrainian].

4. Rozporiadzhennia KMU «Kontseptsiia reformuvannia mistsevoho samovriaduvannia ta terytorialnoi orhanizatsii vlady v Ukraini» [MU Resolution «Concept of Reform of Local Self-Government and Territorial Organization of Power in Ukraine»]. (2014, April 01). Retrieved from https://zakon.rada.gov.ua/laws/show/333-2014 [in Ukrainian].

5. Nova Ukrainska Shkola. Ninisterstvo osvity I nauky Ukrainy [New Ukrainian School. Ministry of Education and Science of Ukraine]. (2016). Retrieved from https://www.kmu.gov.ua/.../ukrainska-shkola-compressed.pd [in Ukrainian].

6. Bilianin, H .I., (2014). Suchasni innovatsii v systemi osvity Chernivetskoi oblasti [Modern innovations in the education system of the Chernivtsi region]. Retrieved from https:// irbis-nbuv.gov.ua/.../cgiirbis_64.exe? [in Ukrainian].

7. Bodelan, V. R., (2014). Pravovi osnovy hromadsko-derzhavnoho partnerstva: zarubizhnyi i vitchyznianyi dosvid [Legal basis of public-public partnership: foreign and domestic experience]. Retrieved from https://official.chdu.edu.ua/article/viewFile/60352/56153 [in Ukrainian].

8. Bondarenko, M. (2008). Sotsialnyi dialoh: pryvid dlia rozmovy chy rishuchykh dii [Social dialogue: an occasion for conversation or decisive action]. Pravovyi tyzhden, 40, 173-175 [in Ukrainian].

9. Bukovynska, M. P. (2010) Umovy i pryntsypy funktsionuvannia v osviti sotsialnoho partnerstva [Conditions and principles of functioning in the education of social partnership]. Retrieved from https://www.rusnauka.com/15_APSN_2010/Economics/67941.doc.htm [in Ukrainian].

10. Varenytsia, V. A. (2009). Stanovlennia novoi modeli sotsialnoho dialohu v suchasnii Ukraini: sotsiolohichnyi analiz [The formation of a new model of social dialogue in Ukraine: a sociological analysis]. Extended abstract of candidate's thesis. Kharkiv: Kharkiv National University of Interior Affairs [in Ukrainian].

11. Volkova, V. (2016). Orhanizatsiia navchalno-vykhovnoho protsesu na zasadakh pedahohiky partnerstva v umovakh realizatsii kontseptaii Novoi ukrainskoi shkoly [Organization of the educational process on the basis of partnership pedagogy in the context of the implementation of the concept of the New Ukrainian School] Retrieved from https://naurok.com.ua/organizaciya-navchalno-vihovnogo-procesu-na-zasadah-pedagogiki-partnerstva-v-umovahrealizaci-koncepci-novo-ukra-nsko-shkoli-5829.html [in Ukrainian].

12. Vyshnevskyi, O. (2006). Teoretychni osnovy suchasnoi ukrainskoi pedahohiky [Theoretical foundations of modern Ukrainian pedagogy]. Drohobych: Kolo [in Ukrainian].

13. Yezhova, O. Ye. (2011). Stvorennia osvitnoho seredovyshcha spriamovanoho na formuvannia tsinnisnoho stavlennia do zdorovia $\mathrm{v}$ uchniv profesiino-tekhnichnykh zakladiv [Creation of an educational environment aimed at the formation of a value attitude towards health at the students of vocational education and training institutions]. Retrieved from https:// lib.iitta.gov.ua/.../Yezhova_Stvorenny_osvitnoho_seredovys..

14. Kolot, A. (2009). Sotsialne partnerstvo na zlami dvokh tysiacholit: stan, vyklyky, tendentsii rozvytku (na prykladi krain Yevropeiskoho Soiuzu [Social partnership at the turn of two millennia: state, challenges, development trends (for example, the countries of the European Union) ]. Sotsialna polityka: problem, komentari, vidpovidi - Social policy: problems, comments, answers, 1, 26-28 [in Ukrainian].

15. Koroliuk, S. V. (2010). Osoblyvosti hromadsko-derzhavnoho upravlinnia v diialnosti suchasnoi shkoly [Features of public administration in the activities of the modern school]. Teoriia ta metodyka upravlinnia osvitoiu Theory and methodology of education management, 3, 1-13 [in Ukrainian].

16. Kravchynska, T.S. (n.d.). Pedahohika partnerstva - osnovni idei, pryntsypy ta sutnist [The pedagogy of partnership is the main ideas, principles and essence]. Retrieved from https:// lib.iitta.gov.ua/707221/1/Кравчинська_тези.pdf [in Ukrainian].

17. Kudriachenko, A.I. (2008). Sotsialne partnerstvo: yevropeiskyi dosvid I Ukraine [Social partnership: European experience and Ukraine]. Strategic priorities, 3(8), 132-141 [in Ukrainian].

18. Makar, L. M. (2013). Sutnist osvitnoho seredovyshcha v pedahohichnomu protsesi [The essence of the educational environment in the pedagogical process]. Pedahohika formuvannia tvorchoi osobystosti u vyshchii I zahalnoosvitnii shkolakh - Pedagogy of the formation of a creative person in higher and secondary schools. (Issue 30), (pp. 229-236). Retrieved from http://nbuv.gov.ua/UJRN/Pfto_2013_30_37 [in Ukrainian]. Ukrainian].

19. Shchokin, H. V., \& Holovatyi, M.F. (Et al.) (2007). Menedzhment [Management]. Kyiv: MAUP [in

20. Nikolenko, L. (2018). Pedahohika partnerstva yak umova realizatsii zavdan rozvytku osobystosti dytyny u konteksti Novoi ukrainskoi shkoly [Pedagogy of partnership as a condition for realization of tasks of development of the child's personality in the context of the New Ukrainian school]. Retrieved from https:// 
lib.iitta.gov.ua/.../Ніколенко Методист Ст.\%20Педаг.\%20партнерства\%20як\%20y [in Ukrainian].

21. Novikov,V. (1998). Zarubizhnyi dosvid sotsialnoho partnerstva [Foreign experience of social partnership]. Ukraine: aspekty pratsi - Ukraine: aspects of labor, 1, 38-41 [in Ukrainian].

22. Poliak, O. V. (2018). Menedzhment osvitnoho seredovyshcha ta yoho vplyvy na formuvannia novoi ukrainskoi shkoly [Management of the educational environment and its influence on the formation of a new Ukrainian school]. Proceedings from MIIM '18: XXV Mizhnarodna naukovo-praktychna internet-konferentsiia «Naukovi pidsumky 2018 roku» - XXV International Scientific and Practical Internet Conference «SCIENTIFIC RESULTS OF 2018». (part 7) (pp. 45-49). Vinnytsia: «Pedahohichni nauky» - «Pedagogical sciences» [in Ukrainian].

23. Savranska, H. M. (2014). Mizhsektorne sotsialne partnerstvo yak osnova sotsialnoi bezpeky derzhavy [Crosssectoral social partnership as the basis of social security of the state]. Naukovo-informatsiinyi visnyk Akademii natsionalnoi bezpeky - Scientific and Information Bulletin of the Academy of National Security, 1, 93-105 [in Ukrainian].

24. Popova, S. V. (2014). Sotsialne partnerstvo ta autsorsynh yak napriamy pidvyshchennia efektyvnosti nadannia sotsialnykh posluh $\mathrm{v}$ Ukraini [Social partnership and outsourcing as a way of increasing the efficiency of providing social services in Ukraine]. Teoriia ta praktyka derzhavnoho upravlinnia - Theory and practice of public administration, 1, 156162 [in Ukrainian].

25. Todosova, H. I., (n.d.). Shliakhy rozvytku derzhavno-hromadskoho upravlinnia osvitoiu v Ukraini: yevropeiskyi dosvid ta ukrainska realnist [Ways of Development of Public-Public Education Management in Ukraine: European Experience and Ukrainian Reality]. Retrieved from https:// www.academy.gov.ua/ ej/ej11/txts/10thidur.pdf [in Ukrainian].

26. Trunova, H. A. (2007). Derzhava yak subyekt sotsialnoho partnerstva [The state as a subject of social partnership]. Pidpryiemntstvo, hospodarstvo I pravo: Shchomisiachnyi naukovo-praktychnyi hospodarsko-pravovyi zhurnal - Entrepreneurship, economy and law: A monthly scientific and practical economic and legal journal, 1, 29-35 [in Ukrainian].

27. Ukrainets, R., (n.d.). Uzhodzhuvalni zustrichi - odyn $\mathrm{z}$ diievykh zasobiv perehovornoho protsesu $\mathrm{u}$ pryskorenni vyrishennia kolektyvnykh trudovykh sporiv (konfliktiv) [Co-ordination meetings are one of the most effective means of negotiating process in accelerating the resolution of collective labor disputes (conflicts)]. Retrieved from http://www.nspp.gov.ua/index.php?option=com_conten [in Ukrainian].

28. Tsiura, S. B., (2012). Novi modeli sotsialnoho partnerstva shkoly I simyi: pryvatna zahalnoosvitnia shkola $\mathrm{v}$ Ukraini [New models of social partnership of schools and families: a private secondary school in Ukraine]. Retrieved from http://www.irbis-nbuv.gov.ua/cgi-bin/irbis_nbuv/cgiirbis_64.exe? [in Ukrainian].

29. Chanysheva, H. I., (2015). Sotsialnyi dialoh yak instytut trudovoho prava [Social dialogue as an institute of labor law]. Naukovyi visnyk Mizhnarodnoho humanitarnoho universytetu - Scientific Herald of the International Humanitarian University. (Vol. 2), 18, 4-6 [in Ukrainian].

30. Yavorskyi, M., (n.d.). Hromadsko-derzhavne partnerstvo pry pobudovi rehionalnoi innovatsiinoi systemy [Public-public partnership in the construction of a regional innovation system]. Retrieved from: http://www.cstei.lviv.ua [in Ukrainian].

\title{
ВЗАИМОВЛИЯНИЕ НА МЕНЕДЖМЕНТ «ПЕДАГОГИКИ ПАРТНЕРСТВА» В УСЛОВИЯХ РЕАЛИЗАЦИИ ЗАДАНИЙ НОВОЙ УКРАИНСКОЙ ШКОЛЫ
}

\author{
Билянин Григорий Иванович \\ кандидат педагогических наук, доцент, директор \\ Институт последипломного педагогического образования Черновиикой области
}

Поляк Александра Васильевна

кандидат наук государственного управления, доцент кафедры педагогики, психологии и теории управления образованием Институт последипломного педагогического образования Черновицкой области

У научной статье проанализировано взаимовлияние современных типов среды (сочиальной, государственной, инклюзивной, полноченной жизненной и других) как составляющих новой образовательной среды и видов партнерства (сочиального, государственного, общественного и других) в условиях реформирования образования, учебных заведений и органов местного самоуправления. Освещена потребность действенности менеджмента «педагогики партнерства» для реализации ключевого задания Новой украинской школь: формирование выпускника учебного заведений как личности - патриота - инноватора.

Ключевье слова: менеджмент, образовательная среда, социальное партнерство, государственнообщественное партнерство, Концепџия новой украинской школь, Концепџия реформирования органов местного самоуправления.

Отримано редакцією 15.04 .2019 р. 